\title{
LABOUR RELATIONS OF MEMBERS OF COOPERATIVES IN THE SLOVAK REPUBLIC PRACOVNÉ VZŤAHY ČLENOV DRUŽSTIEV NA SLOVENSKU
}

\author{
Monika SEILEROVÁ*
}

\section{Introduction}

In the current legal situation - de lege lata - of the Slovak Republic Cooperatives have a specific legal position that represents a residue of the previous social era. A distinct character of Cooperatives distinguishing them from other kinds of commercial entities derives primarily from their legal name designated in the systematic part of the Commercial Code (Part II, Section56-260, Companies and Cooperatives). It is also supported by the legal definition of their business purpose provided in Section 221 subsection 1 of the Commercial Code pursuant to which Cooperatives may both pursue profit-making business (the same as with companies), and ensure economic, social and other needs of their members. As a logical result of their specific economic status, the position of Members of Cooperatives is not unambiguous, as well. Stagnation may be observed not only in the context of their economic benefits, but also in the spectre of their legal framework. Comparing the wording of the provisions of the Labour Code of 1965 with those of the currently effective Section 4 of the Labour Code, the Act No. 311/2001 Z. z. (Coll.), we will find that they are identical. The current legislation (de legelata) provides that "labour relations between a Cooperative and its Members are governed by this Act unless otherwise provided in a special regulation. "In this paper we are therefore concerned with consequences of status quo maintained in the legal position of those Members of Co-

\section{Abstract (EN)}

The issue of labour relations between a cooperative and its members is a quite few frequent subject of interest in the area of scientific public. Specificities of previous legislation of the position of members of cooperatives whose members' relations are determined by the labour - law relations are also reflected in the current regulation. There absent rational reason of different approach. In the paper we deal with a short consideration of coherence between the Labour Code and the Commercial Code of the Slovak republic, highlighting the importance of the statutes of the cooperative. We also deal with the theoretical and practical issues resulting from analyzed acts with the effort to appeal to the necessity of unification the legislation of labour relations of nonmembers of cooperative with relations of members of cooperative. The basic consideration de lege ferenda is to constitute the conformity of current regulation to prevent the application uncertainty.

\section{Keywords (EN)}

labour relations, members of cooperative, legislative obsolescence

* Pavol Jozef Šafárik University, Košice, Slovakia operatives whose membership derives from the labour relationship toward a Cooperative derived from the Labour the Code and Commercial Code. As a result of this dichotomy, not unexpectedly, there are several theoretical and application questions arising, which bring an uncertainty into the legal system.

\section{Interconnections between the Laws Regulating Legal Relations of Members of Cooperatives}

Determination of a legal position of Members of Cooperatives directly depends on the subject-matter scope of the applicable legal regulations that may be taken into account. Major legal sources concerning Cooperatives include the Commercial Code, the Act No. 513/1991 Zb. /Coll./(hereinafter referred to as "the Commercial Code") and the Labour Code, the Act No. 311/2001 Z. z. /Coll./, as amended (hereinafter referred to as "the Labour Code"). As for its subject-matter scope in relation to the Commercial Code, the Labour Code represents a special piece of legislation, which is to be applied as a subsidiary source in the case where the Commercial Code is "silent", or where it provides a different definition. However, the space between the Labour Code and the Commercial Code, is occupied by the "rule/norm"or

\section{Abstrakt (SK)}

Problematika úpravy pracovných vztahov členov družstiev je častým predmetom záujmu odbornej verejnosti. Špecifiká doterajšej právnej úpravy pozície členov družstiev, ktorých členstvo je upravené pracovnoprávnymi vztahmi, sa odráža aj v súčasnej legislatíve. V praxi absentuje racionálny dôvod pre zmenu prístupu. Príspevok obsahuje krátku úvahu 0 súlade medzi Zákonníkom práce a Obchodným zákonníkom Slovenskej republiky, berúc do úvahy aj význam stanov družstva. Príspevok sa tiež zameriava na teoretické a praktické otázky vyplývajúce z analyzovaných zákonov so snahou zdôraznit' nutnost' zjednotenia právnych predpisov pracovnoprávnych vztahov nečlenov a členov družstva. Základná úvaha de lege ferenda je zosúladit’ súčasnú úpravu, aby sa zabránilo nejasnostiam pri aplikácii.

\section{Klúčové slová (SK)}

pracovné vzt’ahy, členovia družstva, zastarávanie práva 
"agreement" of its own legal nature into which a whole range of provisions are projected exceeding the frame laid down by the Commercial Code and/or the Labour Code. The latter observation applies where the rules are related to dispositive provisions and not contradicting cogent provisions of the Commercial Code. "Cooperative's Articles (stanovy družstva) are the fundamental corporation instrument similar to a Company's Memorandum of Association." "(1)

The nature of Articles may be examined from two points of view, i.e. as a regulatory instrument whose nature is to be classified as being close to the law, oras an agreement, i.e. as a joint expression of will of several persons. Defining Articles as a specific category of norm also depends on the theoretical and legal definitions of what may be considered a norm. V. Knapp states "norm, in its original, general meaning, means a rule prescribing what the behaviour/status should be."(2) We fully concur with the opinion that: “...Articles represent something like an act of private law/norm-making. Meeting of Members (členská schôdza) becomes a secondary lawmaking body privatizing the legislative power normally reserved for the state legislator." ${ }^{\text {(3) }}$ Although we may call them "norms", it is more likely that they resemble internal acts of an employer of an enterprise, or a normative section of Collective Agreements whose nature is, in this respect, close to that of the law. Nevertheless, regarding the lack of their meeting formal and material criteria, their approximation to the nature of legal norms may be undoubtedly excluded. The fact that the nature of Articles is specific and that they show features of a specific category of norm is also supported by one of the Resolutions of the Supreme Court of the Slovak Republic, case 4 Obdo 20/2009. By dismissing an extraordinary appeal the Supreme Court of the Slovak Republic held that should Articles be modified by an Amendment executed to modify the wording of the original Articles, which lay down different rules for establishment, and termination of membership, the said Amendment shall not have a retroactive effect.

On the other hand, majority of authoritative authors view the operation of Articles as expressing private legal autonomy of individuals, i.e. Members of a particular Cooperative. I. Štenglovástates that „their purpose is to express a free will of Members of a Cooperative to submit their interests and conduct to the common interests of a jointly created entity, a will to observe the obligations assumed voluntarily and to bear the consequences of joint actions. " ${ }^{\text {(4) }}$ Accepting Articles as an expression of will of private persons is typical of various kinds of private contracts as fundamental forms of contractual autonomy exercised by individuals. They may be therefore compared to a legal act whose consequences relate to the establishment, modification or termination of particular rights and duties. According to experts and judi-

(1) PATAKYOVÁ, M. et al., Commercial Code. Commentary. 3. ed. Praha: C. H. Beck, 2010, p. 696.

(2) KNAPP, V. Theory of Law, Praha: C. H. Beck, 1999, p. 147.

(3) PORUBAN, A., Legal framework of dependent work in employment between the cooperative and its member. p. 91. In: Studia Iuridica Cassoviensia.Košice, y. 3, no. 2. p. 92.

(4) ŠTENGLOVÁ, I. - PLÍVA, S. - TOMSA, M., Commercial Code. 12. ed.. Praha: C. H. Beck, 2009, p. 779-780. cial decisions, Articles represent a "sui generis contract". (SJ 10/2003, p. 799) $)^{(5)}$ Determining the legal nature of Articles as a sui generis contract is relevant when considering if they are valid or void. It is rather obvious that if Articles were contradicting cogent provisions of the Commercial Code, a Cooperative would fail to be established and, at the same time, such Articles would have to be found void. However, in the case where Articles are treated as a multilateral sui generis legal act, their validity must be considered in terms of invalidity reasons of a legal act pursuant to the Civil Code, the Act No. 40/1964 Zb. (Coll.), as amended (hereinafter referred to as "the Civil Code"). Pursuant to the provision of Section 39 of the Civil Code, a legal act is void if its content or purpose is contrary to the law, if it evades the law, or is contrary to the principles of morality. Case law confirms that examination whether Articles are or are not contrary to the morality principles isrequired by the provision of Section 39 of the Civil Codewhen considering in/validity of legal acts. It is therefore necessary to support the opinion that the nature of Articles is that of a "sui generis contract", i.e. a joint expression of will of several persons which, as legal acts do, brings about certain legal consequences. ${ }^{(6)}$ Categorization of Articles is significant especially when considering their validity or invalidity from a point of view of those provisions of the Articles that are of a commercial-law nature, but certainly also from a point of view of the provisions concerning the labour law. In the light of the labour law considerations, finding Articles contrary to the cogent provisions of the law would not be so simple regarding an indefinite nature of persisting legal regulations. Their specific character in the context of labour law is substantial for the reason that itis the Articles that are the norm, or "agreement" which legitimate attendees of a Meeting of Members to adopt the rules laying down a specific labour-law status of Members of Cooperatives which differs from the rules provided for in the Labour Code.

\section{Position of Members of Cooperatives in the context of individual employment relations}

The Commercial Code lists obligatory particulars of Articlesdispensing, which a Cooperative cannot be entered in the Business Register (Section 226 subsection 1). Pursuant to the provision of Section 226 subsection 2 of the Commercial Code, one of facultative particulars includes determination of employment relations of Members of Cooperatives. There is a rule that Articles may lay down particulars of the employ-

(5) ŠTENGLOVÁ, I. - PlíVA, S. - TOMSA, M., Commercial Code. 12. ed. Praha: C. H. Beck, 2009, pp.779-780.

(6) For example, the Resolution of the Supreme Court of the Czech Republic, case 29 Cdo 1245/2009, in which it was held that the payment of a settlement share is to be performed by way of equal instalments to be paid during 20 years, whereas the first instalment shall be payable only after the expiry of 2 years after the approval of Financial Statements when the membership has terminated is contrary to the principles of morality. 
ment relationship of Members toward a Cooperative if, according to the Articles, membership is also conditioned by employment of a Member with a Cooperative. On the other hand, it is simultaneously laid down that specification of an employment relationship in the Articles may not be contrary to the labour law, except where such employment conditions are more favourable for a Member. If Articles do not specify the employment relationship separately, labour law should be applied in the full extent.

As results from the wording of the law, in the case where a membership is determined by the performance of work for a Cooperative, Articles may incorporate into their wording employment conditions differing from the Labour Code. It can also be discussed if statutory permission to deviate from the wording of the Labour Code is absolute, i.e. permission to differ from any provisions of the Labour Code, or relative, i.e. the wording in the Articles may only differ from dispositive and relatively cogent provisions of the Labour Code. As H. Barancováputs it: "...Articles of a Cooperative may not be contrary to the labour law regulations of a cogent nature."However, she further adds that "the appendix "unless it is more favourable for a Member" as if suggested that if thewording contained in the Articles is favourable for a Member, then it may be contrary to the labour laws. ${ }^{\text {(7) }}$ A. Poruban, on the other hand, states that: "It would be completely in contradiction to an overall meaning and purpose of the provision of Section 226 subsection 2 of the Commercial Code to interpret it as allowing the wording contained in the Articles not to comply even with the cogent labour law rules ifit is more favourable for Members. Articles cannot go beyond the Labour Code and cannot provide for what is not known to the Labour Code (disciplinary measures, other sanctions, contractual penalties). ${ }^{(8)}$ "We cannot agree with his opinion. First of all, in order to settle this theoretical legal issue it seems crucial to properly interpret the appendix what may be considered as more favourable for a particular Member of a Cooperative. Regarding the fact that, as stated by J. Trojan: "... what is more favourable for a Member is a relative issue since there might be differences in interpretation of favourability between theory and practise when comparing particular labour law relations ${ }^{\text {"( }(9)}$ this question cannot be considered unambiguous as a result of which direction of legally permitted deviation from particular provisions of the Labour Code cannot be taken as peremptory. In many cases the favourability of conditions is understood differently-an employed Member may find more favourable something, which, on the other hand, is not taken as more favourable by a Cooperative, and vice ver$s a .{ }^{(10)}$ This may concern, for example, the maxims, which the lawmaker cogently lays down in relation to working hours.

(7) BARANCOVÁ, H. Labour Code. Commentary. 3. ed., Bratislava: C. H. Beck, 2013, p. 95.

(8) PORUBAN, A. Legal framework of dependent work in employment between the cooperative and its member, In: Studia Iuridica Cassoviensia, y. 3, no. 2, p. 91.

(9) TROJAN, J. Labour Relations of Members of Agricultural Cooperatives and The Contractual Principal. In: Collection of Proceedings from the Symposium. Brno: Masaryk University, p. 53.

(10) SUCHÁNEK,J. Cooperations and Commercial Code. In: Právnik, y. 1992 , no. 8, p. 724
The employee is willing to work above the statutory limit of 400 hours overtime only to earn more for the work done. It may also concern a whole range of issues concerning the labour safety rules. A Member may find their observance as less favourable for himself since their observance may hinder him in increasing his work performance, thereby decreasing his chances to earn more although at a risk of industrial accident or industrial disease. A cooperative, on the other hand, will find it more favourable to observe those rules since it may get rid of its own portion of liability for such industrial accidents. $^{(11)}$

As for the application of the rule, several practical questions arise. The Labour Code shall be fully applied to employment relations of non-members of Cooperatives. This simple application rule is complicated with Members of Cooperatives whose membership depends on the establishment of an employment relationship with a Cooperative. Ad absurdum, we can imagine a situation where a current non-member, and at the same time, an employee of a Cooperative applies for membership. Articles entrench the employment relationship with a Cooperative as a condition of membership whereas their content implies employment rules different from the Labour Code.The subject of activities will be identical with the current performance of work for a Cooperative as employee. Should we follow the wording of the law, we assume that the original employment will terminate in any of statutorily permitted modes of termination within the meaning of the provisions of the Labour Code. Subsequently, the newly admitted Member will enter into an employment contract which will be governed by the provisions of Articles, despite of the fact that the subject of performance of work under an employment contract will be identical for both a Member as well as non-member of a Cooperative. Such a theoretical construction may even be extended by the fact that the new legal framework operating in compliance with the wording of the Articles would seem lessfavourable to a Member of a Cooperative if compared to his preceding rights and duties derived from the provisions of the Labour Code. Could a particular Member of a Cooperative successfully enforce the rights integrated in the Articles that are more favourable for him, and those which are more favourable for him in the Labour Code, despite of the fact that a Cooperative would treat the application of Articles as more favourable for its Members? We assume that what follows from this legal construction is a necessity to take into account primarily the interests of a Members of a Cooperative and his protection. The current legal situation, however, may result in useless disputes when harmonizing interests of a Member and a Cooperative as a whole. From a practical point of view, the Members of a Meeting of Members should reasonable foresee potential complications and should lay down the same legal rules for both Members as well as non-members. We therefore concur with opinions, which consider "separate rules for employment of Members of Cooperatives as currently obsolete", "as residue of the socialist labour law..."(12)

(11) SUCHÁNEK, J. Cooperations and Commercial Code. In: Právnik, 1992, y. 8, p. 724.

(12) PORUBAN, A. Legal framework of dependent work in employment between the cooperative and its member. In: Studia Iuridi- 
Ambiguities described above are aimed to support a conclusion that distinct "employment" rules for Members of Cooperatives eventually bring about excessive complications and lack of unification of employment relationship of employees - non-members and employees - Members of Cooperatives. Even in the respective categories of Companies, drawing and signing of a Memorandum of Association is the fundamental prerequisite of the establishment and incorporation of a Company, whereas the lawmaker does not provide for an option of different determination of employment relations therein.

Provisions of Section 277 subsection 1 of the Commercial Code may be considered a significant sign of attempts atpartial harmonization of legal rules, according to which: "If, as laid downin the Articles, membership is conditioned by an employment relationship toward a Cooperative, to qualify for membership you must be a natural person who has completed mandatory school attendance and has attained 15 years of age."In general, membership is not age-limited under the Commercial Code. Here we may hesitate between two categories of Cooperatives. There are Cooperatives whose Members may include persons who have not attained 14 years of age, and others where the minimum age limit of 15 , at the same time, qualifies as the meeting of the condition of completion of mandatory school attendance. Members of Cooperatives whose membership is determined by establishing an employment relationship will be authorised to act independently in employment relations even in this minimum age category. A "dual regime" will be created consisting in the fact thatthese persons will proceed autonomously in employment relations, however, in other relations they will have to be represented by their legal representatives/guardians. M. Patakyovástates that "any natural person may become a Member of a Cooperative (except for those where the membership in a Cooperative is conditioned by an employment relationship toward a Cooperative), i.e. even such a natural person that has no legal capacity to act, whether at all or partially. In such a case, any and all legal acts of a person not having capacity to act legally must be performed by its legal representative/guardian."(13) An interesting question arises as to membership of particular bodies of a Cooperative. Pursuant to the provision of Section 238 subsection 1 of the Commercial Code there is a rule that only those Members of a Cooperative may be elected to its bodies that are older than 18 years of age, whereas these conditions may not be applied to the supreme body of a Cooperative, which is a Meeting of Members. Consequently, a situation occurs where in the Cooperatives whose membership is conditioned by employment in that Cooperative, persons who are younger than 18 years of age may not take an active partin the election to the bodies of such Cooperative. This causes "imbalance" in rights and duties of particular Members, violating one of the fundamental principles of the Cooperative system, which is the equality of its Members. ${ }^{(14)}$

ca Cassoviensia,Košice, y. 3, no.2, p 92.

(13) PATAKYOVÁ, M. and col., Commercial Code. Commentary 3. Ed. Praha: C. H. Beck, 2010, p. 697.

(14) POKORNA, J. (et. al.), Companies and Cooperatives, 1. Ed., Praha: C. H. Beck, 2014, p. 304.
A specific approach is also considered as to the origination and termination of membership. Pursuant to the provision of Section 227 subsection 3of the Commercial Code, there is a rule that if Articles condition membership by employment of a Member with a Cooperative, and in the absence of anything to the contrary in the Articles, membership shall start on the day when a new employment contract is executed, and it shall terminate on the day of termination of a Member's employment with a Cooperative.The only exception is allowed in the commercial law context where Members of a Cooperative are privileged by the law-maker in being permitted to entrench in their Articles deviating options of the moment of origination and termination of membership. However, there is also a rule that "the employment starts on theday which has been agreed as the day of commencement of employment, but the membership rights come into existence only on the day of payment of the initial contribution. Hence, membership does not start prior the paying up of initial contribution." (15)

Provision of Section 231 of the Commercial Code subsection 1 contains a list of modes when the membership terminates if we synthetize the said provisions with the provision on the origination and termination of membership in the case of Members performing work for a Cooperative as employees, we may assume that the said provision has a specific nature in relation to a general provision on the modes of termination of membership. Therefore, in the case where employment is ended in any of the modes admissible under the Labour Code, this will automatically void membership without a necessity to apply the provision of Section 231 of the Commercial Code. In practise, however, there might occur a situation where a person - a Member of a Cooperative will qualify for being excluded therefrom. Reasons of exclusion concern internal circumstances of a Cooperative that may or may not be associated with the performance of work for a Cooperative under employment contracts, for example where a Member of a Cooperative has repeatedly breached his membership duties, despite of being warned thereof. Would it be necessary, in such a case, to accompany a decision of the Board of Directors of a Cooperative to exclude one of its Members with a simultaneous termination of employment in one of the modes available under the Labour Code as a separate act? Should we apply a premise that the said provision is a general provision in relation to the provision of Section 227 subsection 3 of the Commercial Code, it will be inevitable to proceed also in compliance with the provisions of the Labour Code. In order to maintain unambiguity it seems optimal to introduce a practise where Articles should provide for the cases where the relationship of a Member is conditioned by being employed by a Cooperative, which would a priori prevent possible application ambiguities.

\footnotetext{
(15) SUCHOŽA, J. HUSÁR, J. and col., Commercial Law. Bratislava: IURA EDITION, spol. s. r. o., y. 2009, p. 626.
} 


\section{Position of Members of Cooperatives and collective labour relations}

Pursuant to Section 1 subsection 1 , the purpose of the Labour Code is to regulate individual as well as collective labour relations. Peculiarities of legal regulation in the case of Cooperatives are also present in the area of collective labour relations. It is rather disputable if there exist true collective labour relations in Cooperatives at all, especially in the light of the fact that the wording of the Labour Code is designed for the kinds of Cooperatives under analysis, (in which membership is conditioned by a Member's being employed with a Cooperative) separately and rather differently from the rules regulating collective labour relations with a "standard" employer

The first specific feature of legal relations "with a collective element" is provision of Section Ilaof the Labour Code that generally defines and classifies the concept of employees' representatives in labour relations. At the same time subsection 2 of that provision lays down that with Cooperatives where membership is conditioned also by employment of a Member with a Cooperative, employees' representative for the purposes of this Act (the Labour Code) is a special body of a Cooperative elected by a Meeting of Members. The law has assigned representatives of employees a whole range of competencies in the area of individual and collective labour relations, allowing them to participate in various decisions of the employer. It could be derived therefrom that for these purposes a special body of a Cooperative should be a body, which is both authorised and obliged to negotiate termination of employment of a Cooperative's Member by notice or withdrawal pursuant to Section 74 of the Labour Code. On the other hand, however, the said rule is excluded by the provision of Section 229 subsection 4of the Labour Code, in which direct participation of employees in the creation of just and satisfactory labour conditions via joint decisionmaking, negotiation, right to be informed or control activities is explicitly granted only to trade unions, employee's councils or employee's confidents.

The lawmaker does not specify any details of establishment of a special body to serve as an equivalent of employee's representatives. Obviously, this issue is to be provided for in the Articles. Pursuant to the provision of Section 237 of the Commercial Code, Cooperative's bodies include Meeting of Members, Board of Directors, Supervisory Commission, and other bodies of a Cooperative to be established under the Articles. What follows from the wording of the Labour Code is simply the fact that it is to be a body elected by the supreme body of a Cooperative which is to be composed of Members of a Cooperative at the same time representing interests of all the Members who will jointly, respecting the principle of equality, also act as employers. Hence, there occurs an overlap of several functions: employer, employee - Member of Cooperative, and representative of employees - Members of Cooperative. This will undoubtedly raise a question of how to identify in this versatile range of relations and bodies a contradiction of interests which should be compromised as to the interests of employer versus visions of employee in the extent permitted by the law.

As follows from the provisions of the Labour Code, mutual consultations inside a Cooperative should result in a resolution to be passed at a Meeting of Members. In standard labour relations conclusions of social dialogue are reflected in a Collective Agreement. Collective Agreement results from negotiations between an employer and a trade union organization, whose interests are practically different, they are contradictory. The very substance of collective bargaining is to harmonize two opposing interests. Pursuant to the provision of Section 231 subsection 5 of the Labour Code, however, a special regime should be applied in which a Collective Agreement is replaced in this kind of Cooperatives by a Resolution of a Meeting of Members. A. Porubanstates that it may be put in doubt that a Resolution as individual decision of a body of a Cooperative is capable of replacing a Collective Agreement which is a bilateral legal act. Regarding thisspecific, not quite unambiguous nature of Articles, although they are perceived in the literature as a sui generis contract, also a Resolution adopted by a Meeting of Members may be viewed as a specific will expressed collectively by Members. We therefore come to the conclusion that both in the case of Articles as well as in the process of adoption of a Resolution of a Meeting of Members there occurs an overlap of statuses/ capacities of one and the same person - a superordinate position of employer - Cooperative, with that of a subordinate person performing work for a Cooperative under an employment contract, and in the context of collective relations, it has even a capacity of a body that is to defend interests of employees - Members of Cooperatives. In such a situation there is no contradiction, no conflict of interests. ${ }^{(16)}$

Disregarding the fact that the lack of uniform legal rules seems, once again, needless, or even legally dubious, in ad absurdum contemplations a question may be elicited as to how to proceed in the case where a Cooperative also employs non-members. Relying on the current wording of effective laws we may come to a conclusion that "dual regulation" will apply: the provisions of Section 1la subsection 1 of the Labour Code will be applied to employees' representatives and simultaneously provisions of Section 1la subsection 2 of the Labour Code will be applied to Members of Cooperatives.

\section{Conclusion}

In the light of the labour law legislation currently applicable to Members of Cooperatives, in every aspect that we have analysed in this article we have ended up with an urgent need for a change. The existing wording of law cannot keep up with the current trend of taking Cooperatives as equal commercial entities pursuing their profit-earning activities. There is no rationale that would substantiate the policy of the legislator to maintain the specific regulation of labour relations of Members of Cooperatives, i.e. to keep them being treated differently from other employees, as legitimated

\footnotetext{
(16) See also: PORUBAN, A., Legal framework of dependent work in employment between the cooperative and its member. In: Studia Iuridica Cassoviensia, y. 3, no.2, 2015, pp.92-93.
} 
via Articles. A whole range of application ambiguities arise that are quite unique in practise, as has been argued, but from a point of view of theory, it cannot be absolutely excluded that they may arise. As a result, currently persising legislative wording result inan excessive lack of unity of legal regulations. We have presented our opinion, which is also supported by several other opinions, of de legeferenda, that in the case where the membership in a Cooperative is conditioned by a Member's employment with a Cooperative, it should be possible to fully apply the rules of the Labour Code, without a possibility of deviating from the effective labour law rules in the Articles.Regarding several deficiencies of the current legislation applicable to the Czech business corporations, the legislation that has been used to exemplify cannot be treated as ideal, but rather as a perspective guide to achieve a change. The Business Corporations Act of the Czech Republic No. 90/2012 Sb. /Coll./on the Companies and Cooperatives, in the provision of Section 579 subsection 1 provides that: ,if Articles condition membership by employment of a Member with a Cooperative, only a person having a capacity to enter into an employment contract may qualify as a Member " and the legislator does not "authorise" the Meeting of Members to permit a deviation from the labour law rules in the Articles.

\section{References}

1. BARANCOVÁ, H. Labour Code. Commentary, 3. Edition.Bratislava: C. H. Beck, 2013, 1075 p., ISBN 9788089602107.

2. KNAPP, V. Theory of Law. Praha: C. H. Beck, 1999, 264 p., ISBN 80-71-79-028-1.
3. POKORNA, J. (et. al.), Companies and Cooperatives, 1 st. ed.., Praha: C. H. Beck, 2014, 414 p., ISBN 9788071004759.

4. PICHRT, J. Work of Member for Cooperative before and after Recodification. In: Acta Universitatis Carolinae Iuridica, č. 4, 2014, pp. 35-49.

5. PATAKYOVÁ, A. and col., Commercial Code. Commentary. 3. Ed., Praha: C. H. Beck, 2010, 1219 p., ISBN 978-80-7400-314-1.

6. PORUBAN, A. Legal framework of dependent work in employment between the cooperative and its member - In: Studia Iuridica Cassoviensia, Košice: Pavol Jozef Šafárik University in Košice. Law Faculty, y. 3., no. 2, 2015, pp. 89-94, ISSN 13393995.

7. SUCHÁNEK, J. Cooperatives and Commercial Code. In: Právnik, y. 1992, no. 8, pp. 712 - 729, ISSN 0231-6625.

8. SUCHOŽA, J. - HUSÁR, J. and col., Commercial Law. Bratislava: IURA EDITION, spol. s. r. o., y. 2009, 1100 p., ISBN 978-808078-290-0.

9. ŠTENGLOVÁ, I. - PlíVA, S. - TOMSA, M., Commercial Code. 12. Ed. Praha: C. H. Beck, 2009, 1375 p., ISBN 9788074000553.

10. TROJAN, J., Labour Relations of Members of Agricultural Cooperatives and the Contractual Principal. In: Contractual Principal and Its Declaration in Individual Law. Collection of Proceedings from the Symposium. - Brno: Masaryk University, 1994, pp. 52-56.

Contact address/ Kontaktná adresa

\section{Mgr. Monika Seilerová, PhD.}

postdoctoral researcher, Department of Labour Law and Social Security Law, Law Faculty,

Univeristy of Pavol Jozef Šafárik in Košice, Slovak Republic, email: monika.seilerova@upjs.sk 